\title{
Effect of Exercise and Resistance Methods on Increasing 800 Meter Range Results
}

\author{
Johni Melvin Tahapary, Moch. Asmawi, James Tangkudung
}

\begin{abstract}
The purpose of the research is to reveal what is to be achieved with the final results 1) Completion of the problems that have arisen to produce new wisdom, 2) Prevent all predicted problems will arise, 3) as a comparison of existing theories. Specifically, the purpose of this study was to determine whether there was a direct influence between training methods and the efficacy of increasing 800 meters running distance at Pattimura University Students Teacher Training and Education Faculty 2015/2016 Physical Education and Recreation Physical Education Study Program. This research was conducted at Patimura University, Faculty of Health and Education, Penjaskesrek Study Program involving 60/17 students in the 2016/17 semester as research subjects. The method used in this study is an experimental method based on SuarsiminArikunto's reference. Experimental research, according to Ali Maksum, is a rigorous study to find out the causal relationship between variables. One of the main characteristics in experimental research is the existence of treatments (treatments) that are worn on the subject or object of the researcher. Research design or research design is a plan and structure of inquiry arranged so that researchers will be able to obtain answers to their research questions. The results showed that to increase the results of 800 meters running in Unipatti Ambon FKIP Penjaskesrek students can be improved through interval training methods, continuous training methods, and fartlek training methods by controlling endurance first.
\end{abstract}

Keywords: Interval Training Method, Contest Training Method, Fartlek Training Method, Endurance, PJKR Students

\section{INTRODUCTION}

Sports is one of the activities carried out to improve body fitness, maintain health while maintaining performance. Besides that, sport is one of the places to shape the mentality and build character, a nation or society. Policy Studies Based on the National Sports System Act of 2005 stated that the scope of the sports system in Indonesia is divided into three components, namely: Sports Education, Recreational Sports, and Sports Achievement.

Through sports activities can minimize differences in the concept of understanding of group or group interests by promoting togetherness, to create a spirit of unity and unity both in regional, national, and international contexts. Thus, through the sport of the name of a region or country, it will be honoured to be able to become champions in various activities at regional and international levels.

It should be realized that the issue of performance of

Revised Manuscript Received on September 22, 2019.

Johni Melvin Tahapary, Department of Educational Sport Universitas Negeri Jakarta and Lecturer at Universitas Pattimura Ambon. johnitahapary77@gmail.

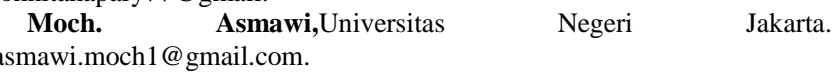

James Tangkudung,Universitas Negeri Jakarta.

james24061952@gmail.com. athletes in achieving achievements is not only about physical problems, in the sense that they are physically strong and will certainly win the match/race, but this is multifactorial (Tangkudung: 2012). This means that not because someone's physical strength is strong, so surely the athlete will excel in every race or competition, but other factors support the success of the athlete, including skills, mentality, anthropometrics, training programs prepared by the trainer and many more other. The appearance of an athlete must be planned and arranged programmatically directed at achieving peak performance in a sport that must be achieved with a systematic and planned effort. This means that the sport of achievement today is very determined by the pattern of guidance that is directed, programmed and systematic in its planning. This also applies to athletic sports specifically for medium distance running numbers.

\section{LITERATURE REVIEW}

Medium distance running movements (800 meters, 1500 meters and 3000 meters) are slightly different from the short distance running (Sprint). Because in medium distance running distance that must be travelled further, middle distance runners must be good at managing strategies in order to win the race. Medium distance runners must be good at saving energy, so they don't experience a decrease in stamina during the race. The 800 -meter running movement seems simple, but an 800-meter run requires adequate physical training and facilities to support and get good achievements. (Basuki, 2016: 67)

Start stands are used for medium distance running (800 meters, 1500 meters and 3000 meters etc) and long distance or marathons (5000 meters, 10,000 meters and 42,195 km). The purpose of this stand is so that the start can be done effectively from a standing position. (Sidik, 2014: 18-19)

Methods are one way to solve problems and even to simplify solving problems. According to James Tangkudung and WahyuningtyasPuspitorini (2012: 46), the training method is a lesson to develop training, where the word method is used for the condition of the activity material. Whereas training according to harsono in Damaeka (2014: 62) argues that training is a systematic process that is carried out repeatedly, and more days the number of exercises increases as well as the intensity of the exercise.

As stated by Fox EL, Bowers RW, Foss ML: there are two principles of training methods used in aerobic and anaerobic sports to achieve sports performance. The first is interval training, which can be adjusted with the variation of needs and the most efficient way to achieve VO2 max. Both exercises are continuous, where in principle there is an adaptation to the aerobic 
component circuit.

Suharto, Wuryanto, and LodewijkSitorus stated: in today's training methodology, there have been a number of methods that have different characteristics from one another. But in principle, the implementation follows scientific rules of practice. The training methods include continuous method, interval method and fartlek method.

Physiologically muscle strength is the ability of a muscle or a group of muscles to make a maximum of one contraction against a prisoner or load, or it can be defined that muscle strength is the ability of a muscle to generate a voltage against a prisoner (Widiastuti, 2011: 76). Muscle strength is the ability of a group of muscles to fight load in one endeavour and muscle endurance is the ability of a group of muscles to do a series of work for a long time (Lubiset al. 2015: 143).

Strength is the ability to fight detention/resistance or physical burden both from outside and from the body itself (Ria, 2013: 55). Strength is the power of muscle contraction that is achieved in a maximum effort; this maximum effort is carried out by a muscle or a group of muscles to overcome resistance (Ismaryati). Besides that, there is also strength or strength, which is an ability of the human physical condition needed in improving the learning achievement of motion. Strength is one element of the physical condition that is very important in exercising because it can help improve components such as speed, agility and accuracy.

Based on the experts' supporters, it can be concluded that strength is the ability of muscles to respond to a load prisoner in one attempt.

The aim of strength training for 800 meter runners is to increase leg muscle strength, and to develop general strength to help prevent injury to the soft tissue found in the leg muscles, these two goals are considered most important for 800 meter runners (Raphael, 2005: 22) In addition there are several types of strength that must be known, namely general strength, special strength, maximum strength, strength endurance, absolute strength, and relative strength.

Physical exercise in its implementation is more focused on the process of fostering the athlete's physical condition as a whole and is one of the main and most important factors that must be considered as an element needed in the training process in order to achieve higher achievement, the main goal is to increase athletes' functional potential and develop biometric abilities to the highest degree.

Through exercise, the physical condition of the athlete's physical fitness can be maintained or improved, both in terms of skills and general health. Physical condition training is the process of developing the ability of physical movement activities carried out systematically and progressively increased to maintain or improve physical fitness levels to achieve optimal physical work ability. Physical condition is a very important element in almost all sports. Therefore, physical condition training needs to get serious attention and carefully planned and systematically so that the level of physical fitness and functional ability of the body becomes better.

Training or training, according to Harsono (2015: 50) is a systematic process of practising or working, which is done repeatedly, with more and more days increasing the amount of training or workload ".

\section{METHODOLOGY/MATERIALS}

In general, the purpose of the study is to reveal what is to be achieved with the final results 1) Completion of the problems that have arisen so as to produce new wisdom, 2) Prevent all predicted problems from arising, 3) as a comparison of existing theories (Subagio, 2004: 13).

Specificall, the purpose of this study was to determine whether there was a direct influence between training methods and the efficacy of increasing 800 meters running distance at Pattimura University Students Teacher Training and Education Faculty 2015/2016 Physical Education and Recreation Health Study Program

This research took place in Pattimura University Campus Teacher Training and Education Faculty Ambon City Physical Health and Recreation Education Study Program. Due to several reasons. The first athletics is one of the compulsory subjects that is developed in the PJKR Study Program FKIP Unpatti so that equipment for athletics/athletics can be used in conducting research. The researcher himself as one of the teaching staff.

The method used in this study is a field experiment method. Experiments are observations carried out by artificial conditions where the conditions are made and arranged by the researcher (Nazir, 2003).

\section{RESULTS AND FINDINGS}

There was a difference between the interval training method and the continuous training method on the results of the 800 meter run in the Teacher Training and Education Faculty of Physical Education and Education at Pattimura University Ambon. 2) There is a difference between the interval training method and the fartlek training method on the results of the 800 meter run on students of the Pattimura University Health and Recreation Health and Education Study Program at the Pattimura University Ambon. 3) There is no difference between the method of continuous training and the method of fartlek training on the results of the 800 meter run on the students of the Physical Education and Recreation Education Program of the Faculty of Teacher Training and Education, Pattimura University Ambon. 4) There is an influence of the interaction between the training method and the resistance to the results of the 800 meter run on the students of the Physical Education and Recreation Education Program of the Faculty of Teacher Training and Education at the University of Pattimura Ambon. 5) There are differences in the results of 800 meters running between interval training methods using high durability with the continuous training method using high endurance in students of the Physical Education and Recreation Education Program of the Faculty of Teacher Training and Education of Pattimura University Ambon. 6) There are differences in the results of 800 meters running between interval training methods using high durability with the method of fartlek training using high durability in students of the Physical Education and Recreation Education Program of the Faculty of Teacher Training and Education of Pattimura University Ambon. 7) There are differences in the results of 800 meters running between the continuous training method using high durability with the method of fartlek training using high endurance in 
students of the Physical Education and Recreation Education Program of the Faculty of Teacher Training and Education of Pattimura University Ambon. 8) There is no difference in the results of the 800 meter run between interval training methods using low durability with the continuous training method using low endurance in students of the Physical Education and Recreation Education Program of the Faculty of Teacher Training and Education in Pattimura University Ambon. 9) There are differences in the results of 800 meters running between interval training methods using low endurance with the method of fartlek training using low endurance in students of the Physical Education and Recreation Education Program of the Faculty of Teacher Training and Education of Pattimura University Ambon. 10) There are differences in the results of 800 meters running between the continuous training method using low endurance with the method of fartlek training using low endurance in students of the Physical Education and Recreation Education Program of the Faculty of Teacher Training and Education of Pattimura University Ambon.

Thus to improve the results of 800 meters run in Unipatti Ambon FKIP Penjaskesrek students can be improved through interval training methods, continuous training methods, and fartlek training methods by controlling endurance first.

\section{A. Discussion}

\section{1) Results of an 800 meter run Group Interval Exercise Method $\left(A_{1}\right)$.}

Based on the research data of the 800-meter run (Y), the lowest score was 123.05; the highest score was 128.65 so that the range was 5.60. From the statistical calculation it was obtained an average value of 125.33 standard deviation (s) of 1.76 and variance amounting to 3.11 and to provide an overview of the frequency distribution of the 800-meter run result (Y) the frequency distribution can be arranged as follows:

Table 4.2. 800-meter running frequency distribution list in group Interval Training Method $\left(\mathrm{A}_{1}\right)$

\begin{tabular}{llllll} 
No & Value Interval & F & X & FX & F Relative \\
\hline 1 & $123.05-124.16$ & 7 & 123.61 & 865.24 & $35.00 \%$ \\
2 & $124.17-125.28$ & 4 & 124.73 & 498.90 & $20.00 \%$ \\
3 & $125.29-126.40$ & 33 & 125.85 & 377.54 & $15.00 \%$ \\
4 & $126.41-127.52$ & 4 & 126.97 & 507.86 & $20.00 \%$ \\
5 & $127.53-128.65$ & 2 & 128.09 & 256.18 & $10.00 \%$ \\
& AMOUNT & 20 & & & $100 \%$ \\
\hline
\end{tabular}

2) $\mathbf{8 0 0}$ meter Run Results Group Continuous

Exercise Method ( $\left.\mathbf{A}_{2}\right)$.

Based on the research data of the 800-meter run (Y), the lowest score was 123.03 , the highest score was 127.33 so that the range was 4.30 . From the statistical calculation, it was obtained an average value of 125.26 standard deviation (s) of 1.10 and variance amounting to 1.85 and to provide an overview of the frequency distribution of the 800-meter runs (Y) can be arranged as a frequency distribution as follows:
Table 4.3. 800-meter running frequency distribution list in the Continuous Training Method group $\left(\mathrm{A}_{2}\right)$

\begin{tabular}{llllll}
\hline No & Value Interval & F & X & FX & Relative \\
\hline 1 & $123.03-123.88$ & 4 & 123.46 & 493.82 & $20.00 \%$ \\
2 & $123.89-124.74$ & 3 & 124.32 & 372.94 & $15.00 \%$ \\
3 & $124.75-125.60$ & 4 & 125.18 & 500.70 & $20.00 \%$ \\
4 & $125.61-126.46$ & 4 & 126.04 & 504.14 & $20.00 \%$ \\
5 & $126.47-127.33$ & 5 & 126.90 & 634.50 & $25.00 \%$ \\
& AMOUNT & 20 & & & $100 \%$ \\
\hline
\end{tabular}

3) $\mathbf{8 0 0}$ meter Run Results Fartlek Exercise Method Group $\left(\mathbf{A}_{3}\right)$.

Based on the research data of the 800 meter run (Y) the lowest score was 123.05 the highest score 128.66 so that the range was obtained 5.61 From the statistical calculation obtained an average value of 125.16 standard deviation (s) of 1.28 and variance of 2.60 and to provide an overview of distribution the frequency of the 800 meter run $(\mathrm{Y})$ can be arranged in the frequency distribution as follows:

Table 4.4. 800-meter running frequency distribution list in the group Fartlek Exercise Method $\left(\mathrm{A}_{3}\right)$

\begin{tabular}{llllll} 
No & Interval Value & F F & X & FX & Relative \\
\hline 1 & $123.05-124.16$ & 5 & 123.61 & 618.03 & $25.00 \%$ \\
2 & $124.17-125.28$ & 5 & 124.73 & 623.64 & $25.00 \%$ \\
3 & $125.29-126.41$ & 55 & 125.85 & 629.25 & $25.00 \%$ \\
4 & $126.42-127.53$ & 4 & 126.97 & 507,888 & $20.00 \%$ \\
5 & $127.54-128.66$ & 1 & 128.10 & 128,099 & $5.00 \%$ \\
& AMOUNT & 20 & & & $100 \%$ \\
\hline
\end{tabular}

4) 800 meter Run Results Group Interval Training Method with High Durability $\left(A_{1} B_{1}\right)$.

Based on the research data of the 800 meter run on ten students in the interval training method group with High Endurance ability $\left(\mathrm{A}_{1} \mathrm{~B}_{1}\right)$ the lowest score was 124.14 and the highest score was 128.65 , so the range was 4.51. From the statistical calculation it was 126, 46 standard deviation (s) is 1.58 and the variance is 2.51 and to give an illustration of the frequency distribution of the 800-meter runs (Y) can be arranged as the frequency distribution as follows:

Table 4.5. 800-meter running frequency distribution list in the group Method of Interval Training with High Endurance Capability $\left(\mathrm{A}_{1} \mathrm{~B}_{1}\right)$

\begin{tabular}{llllll}
\hline No & Interval Value & F & X & FX & relative \\
\hline 1 & $124.14-125.26$ & 2 & 124.70 & 249.40 & $20.00 \%$ \\
2 & $125.27-126.39$ & 2 & 125.83 & 251.65 & $20.00 \%$ \\
3 & $126.40-127.51$ & 3 & 126.95 & 380.86 & $30.00 \%$ \\
4 & $127.52-128.65$ & 3 & 128.09 & 384.26 & $30.00 \%$ \\
& AMOUNT & 10 & & & $100 \%$ \\
\hline
\end{tabular}

5) 800 meter run results in a group of continuous training methods with high durability $\left(\mathbf{A}_{2} B_{1}\right)$.

Based on the research data of the 800 meter run on ten students in the Continuous training method group with High Endurance ability (A2B1) the lowest score was 123.03 and the highest score was 127.33 so the range was 4.30 . From the statistical calculation obtained an average value of 125.23 the standard deviation (s) is 1.56 and the variance is 2.42 and to provide an overview of the frequency distribution of the 800-meter runs (Y) can be arranged as a frequency distribution as follows: 
Table 4.6. 800-meter running frequency distribution list in the group Continuous Exercise Method with High Endurance Capability $\left(\mathrm{A}_{2} \mathrm{~B}_{1}\right)$

\begin{tabular}{llllll}
\hline No & Interval & F & X & FX & $\begin{array}{l}\text { F Value } \\
\text { Relative }\end{array}$ \\
\hline 1 & $123.03-124.10$ & 4 & 123.56 & 494.25 & $40.00 \%$ \\
2 & $124.11-125.17$ & 2 & 124.64 & 249.28 & $20.00 \%$ \\
3 & $125.18-126.25$ & 1 & 125.71 & 125.71 & $10.00 \%$ \\
4 & $126.26-127.33$ & 3 & 126.79 & 380.38 & $30.00 \%$ \\
& AMOUNT & 10 & & & $100 \%$ \\
\hline
\end{tabular}

6) 800-meter Running Results Fartlek Exercise Group with High Durability $\left(\mathbf{A}_{3} \mathbf{B}_{1}\right)$.

Based on the research data of the 800 meter run on 10 students in the Fartlek training method group with High Endurance ability $\left(\mathrm{A}_{3} \mathrm{~B}_{1}\right)$ the lowest score was 123.05 and the highest score was 125.68 so that the range was 2.63 From the statistical calculation it was 124.09 the standard deviation (s) is 0.94 and the variance is 0.88 and to provide an overview of the frequency distribution of the 800 meter run (Y) can be arranged as a frequency distribution as follows:

Table 4.7. 800-meter running frequency distribution list in the group Fartlek Exercise Method with High Endurance Ability $\left(\mathrm{A}_{3} \mathrm{~B}_{1}\right)$

\begin{tabular}{llllll}
\hline No & Value & F & X & FX & $\begin{array}{l}\text { F } \\
\text { Relative }\end{array}$ \\
\hline 1 & Interrelative123.0 & 4 & 123.37 & 493,495 & $40.00 \%$ \\
2 & $5-123.70$ & & & & \\
2 & $123.71-124.36$ & 3 & 124.03 & 372.09375 & $30.00 \%$ \\
3 & $124.37-125.01$ & 1 & 124.69 & 124.68875 & $10.00 \%$ \\
4 & $125.02-125.68$ & 2 & 125.35 & 250.7025 & $20.00 \%$ \\
& AMOUNT & 10 & & & $100 \%$ \\
\hline
\end{tabular}

7) 800-meter Running Results Group Interval Training Methods with Low Durability $\left(A_{1} B_{2}\right)$.

Based on the research data of the 800 meter run on 10 students in the interval training method with Low Endurance ability $\left(\mathrm{A}_{1} \mathrm{~B}_{2}\right)$ the lowest score was 123.05 and the highest score was 126.39 so that the range was 3.34 From the statistical calculation it was 124.19 the standard deviation (s) is 1.09 and the variance is 1.19 and to give an idea of the frequency distribution of the 800 meter run (Y) can be arranged as follows:

Table 4.8. The distribution list frekuwensi results of $800 \mathrm{~m}$ on the group Method Interval Training with the ability Durability Low $\left(\mathrm{A}_{1} \mathrm{~B} 2\right)$

\begin{tabular}{llllll}
\hline No & Interval & F & X & FX & F Relative \\
\hline 1 & $123.05-123.88$ & 4 & 123.46 & 493.85 & $40.00 \%$ \\
2 & $123.89-124.71$ & 3 & 124.30 & 372.8925 & $30.00 \%$ \\
3 & $124.72-125.55$ & 2 & 125.13 & 250.265 & $20.00 \%$ \\
4 & $125.56-126.39$ & 1 & 125.97 & 125.9725 & $10.00 \%$ \\
& AMOUNT & 10 & & & $100 \%$ \\
\hline
\end{tabular}

8) $\mathbf{8 0 0}$ meter run results in a group of continuous training methods with low durability $\left(\mathrm{A}_{2} \mathrm{~B}_{2}\right)$.

Based on the research data of the 800 meter run on 10 students in the continuous training method group with Low Endurance ability $\left(\mathrm{A}_{2} \mathrm{~B}_{2}\right)$ the lowest score was 123.48 and the highest score 127.12 so that the range was 3.64 From the statistical calculation obtained an average value of 125.29 the standard deviation (s) is 1.22 and the variance is 1.48 and to give an idea of the frequency distribution of the 800 meter run $(\mathrm{Y})$ can be arranged as a frequency distribution as follows:

Table 4.9. 800-meter run frequency distribution list in group Continuous Exercise Method with Low Endurance Capability $\left(\mathrm{A}_{2} \mathrm{~B}_{2}\right)$

\begin{tabular}{llllll}
\hline No & value interval & FF & X & FX & Relative \\
\hline 1 & $123.48-124.38$ & 2 & 123.93 & 247.86 & $20.00 \%$ \\
2 & $124.39-125.29$ & 2 & 124.84 & 249.68 & $20.00 \%$ \\
3 & $125.30-126.20$ & 4 & 125.75 & 503 & $40.00 \%$ \\
4 & $126.21-127.12$ & 2 & 126.67 & 253.33 & $20.00 \%$ \\
& AMOUNT & 10 & & & $100 \%$ \\
\hline
\end{tabular}

9) 800 meter running results for low resistance durability $\left(\mathbf{A}_{3} \mathbf{B}_{2}\right)$.

Based on the research data of the 800 meter run on 10 students in the Fartlek training group with Low Endurance ability $\left(A_{3} B_{2}\right)$ the lowest score was 124.05 and the highest score was 128.66 so the range was 4.61 From the statistical calculation it was 126.23 the standard deviation (s) is 1.43 and the variance is 2.05 and to give an idea of the frequency distribution of the 800 meter run (Y) can be arranged as follows:

Table 4.10. 800-meter run result frequency distribution list in group fartlekl Exercise Method with Low Endurance Capability $\left(\mathrm{A}_{3} \mathrm{~B}_{2}\right)$

\begin{tabular}{llllll}
\hline No & Value Interval & F & X & FX & F Relative \\
\hline 1 & $125.05-125.19$ & 2 & 124.62 & 249.2425 & $20.00 \%$ \\
2 & $125.20-126.35$ & 3 & 125.77 & 377.32125 & $30.00 \%$ \\
3 & $126.36-127.50$ & 4 & 126.93 & 507.705 & $40.00 \%$ \\
4 & $127.51-128.66$ & 1 & 128.08 & 128.08375 & $10.00 \%$ \\
& AMOUNT & 10 & & & $100 \%$ \\
\hline
\end{tabular}

\section{CONCLUSION}

Drawing conclusions is based on the findings of factorial experimental research 2 × 3, with independent variables namely training methods including; interval training method, continuous training method, and fartlek training method and the moderate variable is endurance, and the dependent variable is the result of an 800-meter run. The conclusions in this study are in accordance with the submission of hypotheses, from the results of hypothesis testing conducted can be concluded that; to improve the results of 800 meters running in Unipatti Ambon FKIP Penjaskesrek students can be improved through interval training methods, continuous training methods, and fartlek training methods by controlling endurance first.

\section{ACKNOWLEDGEMENTS:}

Thanks to Prof. Dr. Moch. Asmawi, M.Pd and Prof. Dr. James Tangkudung for giving me your guidance, patience, and being the best inspiring supervisors.

\section{REFERENCES}

1. AmungMa'mun. (2014). Development of the Educational Sport in Indonesia:The Policy Study Based on the Law of National Sports System, Bandung, Jurnal Kajian Pendidikan, Juni 2015

2. SidikDikdik Zafar, Mengajar dan MelatihAtletik, Bandung, PT RemajaRosdakarya.

3. DamaekaSuryantoro. (2014). PengembanganVariasiLatihan Dribbling dan Passing, JurnalOlahraga Pendidikan Volume 1, Nomor 1.

4. Harsono. (2015). Periodesasi Program Pelatihan, Bandung, PT RemajaRosdakarya. 
5. HaslanMuhaiminLubis, DelmiSulastri, dan Afriwardi. (2015). HubunganIndeks Massa TubuhdenganKetahananKardiorespirasi, Kekuatan dan KetahananOtot dan Fleksibilitas pada MahasiswaLaki-LakiJurusanPendidikanDokterUniversitasAndalas, Padang, JurnalKesehatanAndalas.

6. Ismaryati. (2009). Tes dan PengukuranOlahraga, Surakarta, Kerjasama Lembaga Pengembangan Pendidikan (LPP) dan UPT Penerbit dan Percetakan UNS (UNS Press) UniversitasSebelasMaret Surakarta.

7. Tangkudung, James dan WahyuningtyasPuspitorini. (2003). KepelatihanOlahraga, Jakarta.

8. Nazir, Moh. Ph.D. (2014). MetodePenelitian, Jakarta, Galia Indonesia.

9. P. Joko Subagio. (2004). MetodePenelitianDalamTeori dan Praktek, Jakarta, RinekaCipta.

10. Lumintuarso Ria. (2010). TeoriKepelatihanOlahraga, Jakarta, Lembaga Akreditasi Nasional Keolahragaan LANKOR).

11. Raphael Brandon. (2005). Training for Endurance, (London, Peak Performance Publishing.

12. Sunarno Basuki. (2016). Kapasitas Vital Paru-paru, Panjang Tungkai, KekuatanOtotTungkai dan PrestasiLari 800 meter, Jurnal Pendidikan VidiaKarya.

13. Sukardiyanto dan DangsinaMuluk. (2011). PengantarTeori dan MetodologiMelatihFisik, Bandung, Lubuk Agung Bandung.

14. Sukirno, H. (2014). PsikologiOlahraga dan Kepelatihan, Palembang, Unsri Press.

15. Widiastuti. (2011). Tes dan PengukuranOlahraga, Jakarta, PT Bumi Timur Jaya.

\section{AUTHORS PROFILE}

Johni Melvin Tahapary

I am Johni Melvin Tahapary and currently I am affiliated with Department of Educational Sport Universitas Negeri Jakarta and Lecturer at Universitas Pattimura Ambon. johnitahapary77@gmail.

Moch. Asmawi

I am MochAsawi and currently I am associated with Universitas Negeri Jakarta. asmawi.moch1@ gmail.com.

James Tangkudung

I am James Tangkudung and I am affiliated with Universitas Negeri Jakarta.james24061952@gmail.com. 